\title{
UNIVERSITY EDUCATION AS A MODERN EUROPEAN TREND OF INITIAL POLICE TRAINING
}

Anastasia I. Berendieieva $\mathrm{PhD}$ in Law, Associate Professor of the Department of Police Administrative Activity of Odesa State University of Internal Affairs

1 Uspens'ka Str., Odesa, Ukraine, 65000 https://orcid.org/0000-0003-2708-3857

anastasiaberendeeva1@gmail.com

\begin{abstract}
The article is devoted to the issues of police education reform. Modern countries have different models of initial police training, based on their historical traditions and modern conditions of functioning of states. The author explored the current situation of police training in England, focusing on the Initial Police Learning and Development Program (IPLDP), because this program was the main among all other police training programs, but now this program is outdated. The author revealed that the current trend in the world is to increase the role of higher education institutions in the education system for training police officers. The example of England and Wales shows that the system of initial training, which is based on short-term training at the level of the police academy with subsequent service in practical units, does not meet the needs of the time and is outdated.

The global trend is to reorient police training from specific practical knowledge, skills and abilities to higher education and the formation of a person with critical thinking and analytical skills, which meets the current challenges facing the police in the fight against crime. The author argues that such training can be carried out only with the involvement of higher education institutions. As examples, some empirical studies confirm this fact. It is pointed out that it is very important for a modern police officer to perform not only a profession, but also an education in this field in order to perform his / her duties. The author analyzes the opinions of foreign researchers on the advantages of university education over training in police academies. The author touches on the issue of reforming police education in Ukraine in terms of introducing a three-level model of police training and proposes to conduct additional research on both modern foreign experience and the advantages, disadvantages and prospects of the proposed model.
\end{abstract}

Keywords: police, training, education, foreign experience, higher education institutions, police training reform. 


\section{PROBLEM STATEMENT IN GENERAL AND ITS CONNECTION WITH IMPORTANT SCIENTIFIC AND PRACTICAL TASKS}

The main slogan of the reform of the Ukrainian police in 2015 was the creation of a new police force, which would be focused primarily on the protection of human rights and freedoms. The reorientation of the police from a law enforcement, punitive task, the key task of which is to fight against crime, to a service body that provides services to the population to maintain public order and security, requires a revision of the very concept of policing. The new ideology of policing is partnership with the population, the unconditional prerequisite of which is, first of all, the people's trust in the police. Gaining trust, as it turned out in practice, is not so simple. A study conducted in 2020 by the Kharkiv Institute for Social Research showed that only $24.5 \%$ of respondents called policing effective in 2020 (Kobzin, Chernousov \& Shherban, 2020). The level of public confidence is influenced by many factors, but this level can be slightly raised by the professional actions of appropriately trained police officers. What training system best meets this need? The law provides for different ways to train people who want to become police officers. The main form today is education in higher educational institutions of the Ministry of Internal Affairs with specific conditions of study, whose graduates, having received education for three (in some cases four) years, receive a bachelor's degree. However, currently, in accordance with the Concept for the Introduction of a Three-Level Model of Police Training approved in 2018, it is planned that the initial professional training will last for six months and, accordingly, does not provide for higher education. On this occasion, a discussion broke out in the scientific community about the best training model for Ukrainian police.

\section{ANALYSIS OF RECENT PUBLICATIONS ON THE ISSUE AND HIGHLIGHTING PREVIOUSLY UNRESOLVED PARTS OF THE OVERALL PROBLEM}

Police training has been studied in the works of many scientists. Researchers have studied various administrative, legal and psychological aspects of training future police officers, including the role of higher education institutions in the Ministry of Internal Affairs in such training. In particular, V. Abroskin (Abroskin, 2020), A. Andreiev (Andreiev, 2017), V. Beschastnyi (Beschastnyi, 2010), S. Mandryk (Mandryk, 2010), A. Movchan (Movchan, 2020), N. Kolomoiets (Kolomoiets, 2011), I. Savelieva (Savelieva, 2019), D. Shvets (Shvets, 2019) paid attention to these issues. In their publications, the researchers proved their views on police education, the location of universities with specific training conditions in this process, as well as other debatable issues regarding the training of future law enforcement officers. However, some aspects have been overlooked.

The purpose of the article is to analyze successful models of initial police training in the world, in particular in England and Wales, and the prospects for the use of positive practices in Ukrainian legislation. 


\section{PRESENTATION OF THE MAIN RESULTS AND THEIR SUBSTANTIATION}

First of all, it should be noted that police training is carried out in two ways: initial training and postgraduate education. Initial training involves training civilians who have expressed a desire to work in the police. Postgraduate education is provided to existing police officers who have decided to improve their level of education. In this article we will talk about the initial training, i.e. the initial training of civilians.

Today in the countries of the world there is no single universal model of police training. This is understandable, because even modern globalization requires consideration of national characteristics. Educational institutions that provide basic knowledge of policing are very different in nature and learning conditions. When writing this article, the idea was to make at least a general classification and identify the main models of initial training in the world, but, having studied a significant amount of literature, the author failed to find universal criteria for a clear separation of such models. Each country in the world has its own specific model of learning, even if they belong to the same region.

The most common option is to undergo initial training in police academies / schools / colleges. The duration of such training varies, but is usually six months to a year, but can be longer. The duration of initial training ranges from 6 months (Houston Police Academy in the USA, CCP Academy Training Center in Canada and Police High School in Poland) to 30 months (German Police High School in Germany) and approximately 18 months at the Estonian Academy of Security Sciences and the Police Academies in Croatia (Dekanoidze, Khelashvili, 2018). Such academies have different status in different countries. In some, the police academy is not only the main in a single national system of police training at various levels, but also the main center of research and development in the field of law enforcement ((Shvets, 2019).

But gradually the countries of the world are moving away from this model. In recent years, foreign scholars have conducted numerous studies on the best approach to police training. Modern crime proves that obtaining knowledge at the level of police academies, where recruits receive a set of minimum necessary knowledge, and this is not enough. Therefore, most countries in the world are reconsidering their views on the police training system and are gradually creating the conditions for police officers to receive higher education. Indeed, the modern police force in any country in the world needs to effectively combat crime. Modern crime has a transnational character, numerous corrupt connections, high digitalization, so to counteract these phenomena, the police need to have a sharp mind and diverse development, which can only be achieved by mastering a large number of disciplines.

Not to mention the opponents of higher education as an allegedly unnecessary basis for modern man, still obtaining such an education significantly distinguishes a person from other people who do not have such education. And here it is not only the level of knowledge, which, of course, is much higher than the holder of a bachelor's degree, but also in worldview. Distinguishing between training and education, Professor M. Haberfeld emphasizes that the purpose of training is to teach a specific method of performing a task or responding to a proposed situation. The discipline is usually narrow in content. Education involves the study of general concepts, ideas, policies, practices and theories (Haberfeld, 2002). That is, in the training that is offered at the level of police academies, they teach, 
in fact, the algorithm of response to various events. But this is not a profession where you can learn certain „formulas” of behavior and that will be enough. Policing involves many situations that are simply unpredictable. And memorized algorithms, of course, will help to solve some problems, but not all. Higher education creates a versatile person who not only has certain knowledge, but first of all is able to see the problem from different angles. The more different knowledge a person has, the more factors he takes into account when making a decision. Such a person is able to anticipate possible difficulties and find a way out of a difficult situation. Also, given that this profession is social, i.e. is built in the plane of man-man, police officers need some knowledge in psychology, because the nature of their activities involves responding to many unusual situations in which they must navigate both within the law and taking into account human psychology. The success of the tasks assigned to them depends on the correct interaction with individuals. For example, Karpechenkova G.V. emphasizes, speaking about the inspector of juvenile prevention, that the acquisition of the necessary skills goes far beyond the legal sciences, involves the use of methods of child psychologist, educator, and sometimes even a facilitator, who initiates and organizes the provision of comprehensive services to children (Karpechenkova, 2019).

One example of how higher education is better than training in police academies is the following. An interesting study was conducted in the United States on the connection between the education received by police officers and the level of force they use in arrest. The study involved 425 police officers from 146 police stations in six states (New York, Arizona, California, Connecticut, New Jersey, and Washington). The researchers concluded that the level of education is directly proportional to the level of use of more nonviolent methods in arrest. Moreover, the higher the education, the less violent measures of influence they used (Vespucci, 2019).

The world's leading countries have long understood the benefits of higher education for practical activities. After analyzing the results of reforming the police education system in Europe and Asia, I. V. Klimenko concluded that, despite different approaches to police training, most European and American researchers have convincingly questioned the need for at least four years of police training, arguing that, compared to their less educated colleagues, police officers with higher education are less authoritarian and dogmatic, more cautious, have better communication skills and are characterized by a more positive attitude to the problems of cooperation with the community (Klimenko, 2016).

In the last few years in England, there has been a reform in the field of police education with a gradual transition to training, which involves a symbiosis of knowledge acquired in universities and practical training in the service of police units. There are several police training programs in England and Wales, depending on their level of education. The Initial Police Learning and Development Program (IPLDP) has been operating since 2006. It is also called traditional, because until 2020 it was the main form of initial training of police officers. The training is based on a two-year program that combines classroom training based on a national policing program with hands-on training (IPLDP, 2020).

This program provides about 35 weeks of study (but this figure is not fixed, as it depends on the curriculum developed in each educational institution separately) in a specific educational institution, followed by a two-year probationary period. This probationary period includes 
actual service in the police under the „supervision” of an experienced officer. Such a service consistently consists of community placement, supervised patrolling, and independent patrolling. As a rule, recruits are assigned to the police department, which is located next to the university. Since 2010, after the successful completion of this program, recruits have been awarded the „Diploma in Policing” (which refers to the 3rd educational level in England (for understanding, the bachelor is equal to the 6th educational level in England, Wales and Northern Ireland). Only then they become skilled police officers. (Shohel, Uddin, ParkerMcLeod \& Silverstone, 2020). But today this training system is considered obsolete, almost non-existent, and only suitable for use in some police departments. For example, the last graduation of police students under this program in Derbyshire took place on October 23, 2020 («It's over», 2020).

IPLD training no longer meets the needs of the police in practice. A newly elected constable must acquire and apply a high level of professional knowledge in a range of complex situations in increasingly complex and diverse communities. But in practice, the IPLDP does not cover all the knowledge and skills needed by new officers. Other public sector organizations, with which the police often work, are moving to a professional basis, with curricula and admission requirements that reflect the level at which their graduates must work.

The IPLDP training program has not kept pace with the demands of frontline policing. A newly-recruited constable must acquire and apply high levels of professional knowledge to a range of challenging situations, across increasingly complex and diverse communities. The service has expressed concern that IPLDP does not cover all the knowledge and skills that new officers need. Other public sector organizations, that policing often works alongside, are moving to a professional footing, with learning programs and entry requirements that reflect the level at which their personnel are required to operate («Policing Education Qualifications» 2020).

So now European countries are moving to the university level of training police officers and getting them not just a profession, but education. This implies close cooperation in higher education institutions. University training programs are the best mechanism for providing systematic professional knowledge, as well as testing applicants in order to verify the acquired knowledge that corresponds to their profession (Clark, Livingstone, Smaller, editors, 2012).

University training programs have been the most pertinent vehicles for providing codified professional knowledge and of testing potential entrants to verify if they have obtained a basic grasp of the body of knowledge of the respective professional discipline.

New approaches to training include broader and deeper training and education for police officers. The new programs are designed to enhance a police officer's ability to adapt to change throughout his or her service. This was achieved by including in such a program the development of problem-solving skills, critical thinking and analysis, reflection, independent decision-making and the implementation of effective practices. It is clear that this program goes far beyond the skills that can be acquired while studying at the Police Academy and corresponds to educational level 6 (i.e. bachelor). Those who have reached this level are well prepared to apply the acquired skills, apply problem-solving strategies and personal judgment in different contexts («Policing Education Qualifications» 2020). It was important 
to ensure that the new programs were designed to enhance a police officer's ability to adapt to change throughout their service. We did this by including the development of skills in problem solving, critical thinking and analysis, reflection, independent decision making and deploying effective evidence-based practice. The resulting curriculum was set at Level 6 of learning. Individuals educated to this level are well equipped to apply transferable skills, problem-solving strategies and personal judgment in various contexts.

It should be noted that while some countries are only moving towards this, in Ukraine police officers have long received legal education and a bachelor's or master's degree. Today, the initial training of police officers in Ukraine is carried out on the basis of higher educational institutions of the Ministry of Internal Affairs with specific training conditions and institutions (institutions) of the National Police operating to ensure the organization of appropriate special training of police officers hired for the first time, as well as advanced training and retraining of junior police, conducting certain types of police training. And it is very unfortunate that there are trends in the opposite direction - the transition from university education to education at the level of police academies. While the world's leading nations are moving forward and seeking to raise the level of police education, some forces in Ukraine see a minimum level of knowledge as sufficient.

One of the arguments of the supporters of this opinion is the insufficient, in their opinion, practical component of training. Sometimes there are situations when, after being hired in a practical unit, a newly appointed police officer may get the impression that the theoretical knowledge obtained in a higher education institution does not correspond to how it is done in practice. But for some reason the fact that the information received by cadets at training is based on the current legislation is not considered. And the fact that sometimes "in practice” is done differently, it may not indicate that graduates have „wrong” knowledge, but that the current employees for various reasons (including due to lack of relevant knowledge), may act in violation of legal norms. Similar situations are typical for other countries, especially those that undermine the value of higher education. As we noted above, the process of transition to higher education in England is in its infancy. And, of course, like everything new, has some resistance. This is clearly illustrated in a scientific study conducted in England and Wales in 2017. Researchers cited numerous facts, constructed and interviewed with graduates, about the attitude of colleagues and managers. Scientists have concluded that the most common reaction was either indifference and, in some cases, outright hostility. And just in the framework of this study, the following dialogue of the officer, who received a higher education, with his colleagues was given: „- Listen, I'm not kidding, but I conducted a study on this. - Not interesting. - But you are doing it wrong. - We are not interested in it. We do it this way" (Hallenberg, Cockcroft, 2017). It happened in England. But the same dialogue, unfortunately, can be heard in Ukraine, when practical workers say the same to a graduate of a higher education institution. This is an extremely negative situation, which in turn leads to legal nihilism and professional distortion. 


\section{CONCLUSIONS AND PROSPECTS FOR FURTHER RESEARCH}

After analyzing foreign publications over the past few years, we came to the conclusion that there is no single unified system of police training, and each country focuses on its national traditions, needs and challenges. A significant number of countries in the world go from training in police academies to obtaining higher education by police officers. One of the successful practices is the reform of police training in England and Wales. In the last few years, there has been a transition from an outdated training system, which provides for short-term training and a two-year probationary period as a police officer, to new forms of training. Today, for some police services, such training is still appropriate, but schools are already ceasing to teach according to this model. New approaches to police training involve working closely with higher education institutions that provide educational services. According to the English reformers, and with which we fully agree, the future of the police lies in the acquisition of university knowledge.

We also agree with scientists that the experience of other countries is very important and should be taken into account. However, excessive attention to the implementation of the experience of foreign systems of training and education of police officers in Ukraine is not justified, as usually our national characteristics, educational traditions and positive results in this area are ignored. Therefore, it is important to combine the standards established in the legal systems of other countries with the proven practice of domestic developments in the educational process (Pavlenko, Sevruk, Kobko, 2017). Therefore, we consider it is necessary to carry out further research in the field of research of positive practices of foreign countries in police education. In this regard, it should be noted that it is important to refer to modern experience, as reforms in this area have been taking place over the past few years, so it is appropriate to use the most up-to-date information describing such reforms, in our opinion, no later than from 2016, but better from 2019.

With regard to the reform of departmental education in Ukraine, we consider it is necessary to study this issue further in terms of advantages and disadvantages. In our opinion, in this regard it is necessary to make an informed decision on the best model of education, which corresponds not only to European trends, but also to Ukrainian traditions and realities. To this end, it is necessary to conduct thorough research on the prospects of the chosen model of learning and prepare an appropriate framework. Unbalanced decisions can lead to the destruction of police education, which in the short term may lead to a decrease in the level of professionalism of police officers and other negative phenomena both in the system of the Ministry of Internal Affairs of Ukraine and in society as a whole.

\section{REFERENCES}

Kobzin, D., Chernousov, A. \& Shherban, S. (2020). National Monitoring of Illegal Police Violence in Ukraine in 2020. Kharkiv Institute for Social Research; Kharkiv Human Rights Group. Kharkiv: LLC „Human Rights Publishing House".

Abroskin, V.V. (2020). Administrative and legal status of higher education institutions of the Ministry of Internal Affairs of Ukraine as subjects of realization of the educational function of the state. Training of police officers in the conditions of reforming the Ministry of Internal Affairs of Ukraine: collection of scientific works V International. scientific-practical conf., 14-16. Kharkiv. 
Andreiev, A.V. (2017). The place of higher education institutions with specific training conditions that train police officers in the higher education system of Ukraine. Scientific Bulletin of Uzhhorod National University. Series: Right, 43(2), 9-12.

Beschastnyi, V.M. (2010). Mechanisms of state management of development of higher educational institutions of the system of the Ministry of Internal Affairs of Ukraine: Extended abstract of doctor's thesis. Kyiv.

Mandryk, S.I. (2010). Administrative and legal status of higher educational institutions of the Ministry of Internal Affairs of Ukraine. Extended abstract of candidate's thesis. Kharkiv.

Movchan, A.V. (2020). Topical issues of training investigators and investigators for the pre-trial investigation bodies of the National Police of Ukraine. Legal bulletin, 12, 157-165.

Kolomoiets, N.V. (2011). Higher educational institutions of the Ministry of Internal Affairs of Ukraine: formation, functioning, modernization. Extended abstract of candidate's thesis. Kharkiv.

Savelieva, I.V. (2019). Administrative and legal support for the training of the National Police of Ukraine. Candidate's thesis. Ternopil.

Shvets, D.V. (2019). Formation of the police officer's personality in the conditions of professional training and professional activity: legal and psychological aspects. Doctor's thesis. Kharkiv.

Dekanoidze, Khatia, Khelashvili, Madlen (2018). Police education and training systems in the OSCE region. Kyiv.

Haberfeld, M. R. (2002). Critical Issues in Police Training. Upper Saddle River: Pearson Education/Prentice Hal.

Karpechenkova, G.V. (2019). Features of juvenile prevention police activity. Innovative pedagogy. Odesa, 10 (2), 79-82.

Vespucci, J. (2019). Police Officers and College Education: The Association of Police Officer College

Education and the Level of Force Used by a Police Officer in Gaining Compliance in Arrest Situations. CUNY Academic Works. Retrieved from https://academicworks.cuny.edu/gc_etds/3072

Klimenko, I.V. (2016). Psychological contexts of police training and police education in foreign studies. Law and Safety, 4, 12-19.

Initial Police Learning \& Development Programme (IPLDP). Retrieved from https://www.redbridge.gov. uk/media/8057/ipldp-updated-003.pdf

Mahruf, M., Shohel, C., Uddin, G., Parker-McLeod, J. \& Daniel Silverstone (2020). Police Education in the United Kingdom: Challenges and Future Directions. DOI: 10.5772/intechopen.92705. Retrieved from https:// www.intechopen.com/books/education-human-rights-and-peace-in-sustainable-development/policeeducation-in-the-united-kingdom-challenges-and-future-directions\#fn1

It's over and out for our IPLDP students. Retrieved from https://www.derbyshire.police.uk/news/ derbyshire/news/news/forcewide/2020/october/its-over-and-out-for-our-ipldp-students/.

Policing Education Qualifications Framework Initial entry routes Learning to date: development and implementation, 2016 to 2019 (2020). College of Policing Limited.

Clark, R, Livingstone, D.W., Smaller, H. editors. (2012). Teacher Learning and Power in the Knowledge Society. Rotterdam, Netherlands: Sense Publishers.

Hallenberg, K., Cockcroft, T.W. (2017). From indifference to hostility: police Officers, organizational responses and the symbolic value of «in-service» higher education in policing. Policing (Oxford): a journal of policy and practice, 11 (3), 273-288. DOI: https://doi.org/10.1093/police/paw055

Pavlenko, S.O., Sevruk, V.G., Kobko, Ye.V. (2017). Training police officers in the conditions of reforming the system of education of the Ministry of internal affairs of Ukraine in accordance with European standards. Science and education, 6, 142-150. 